\title{
Surface ozone in the Southern Hemisphere: 20 years of data from a site with a unique setting in El Tololo, Chile
}

\author{
Julien G. Anet ${ }^{1,2}$, Martin Steinbacher ${ }^{1}$, Laura Gallardo ${ }^{3,4}$, Patricio A. Velásquez Álvarez ${ }^{5,6}$, Lukas Emmenegger ${ }^{1}$, \\ and Brigitte Buchmann ${ }^{1}$ \\ ${ }^{1}$ Laboratory for Air Pollution/Environmental Technology, Swiss Federal Laboratories for Materials Science and Technology \\ Empa, Duebendorf, Switzerland \\ ${ }^{2}$ WSL Institute for Snow and Avalanche Research SLF, Davos, Switzerland \\ ${ }^{3}$ Departamento de Geofísica de la Universidad de Chile, Blanco Encalada 2002, piso 4, Santiago, Chile \\ ${ }^{4}$ Center for Climate and Resilience Research (CR2), Blanco Encalada 2002, Santiago, Chile \\ ${ }^{5}$ Dirección Meteorológica de Chile, Av. Portales 3450, Estación Central, Santiago, Chile \\ ${ }^{6}$ Climate and Environmental Physics, Physics Institute, University of Bern, Bern, Switzerland
}

Correspondence to: Julien G. Anet (julien.anet@bluewin.ch) and Martin Steinbacher (martin.steinbacher@empa.ch)

Received: 12 July 2016 - Discussion started: 7 October 2016

Revised: 24 March 2017 - Accepted: 25 April 2017 - Published: 31 May 2017

\begin{abstract}
The knowledge of surface ozone mole fractions and their global distribution is of utmost importance due to the impact of ozone on human health and ecosystems and the central role of ozone in controlling the oxidation capacity of the troposphere. The availability of long-term ozone records is far better in the Northern than in the Southern Hemisphere, and recent analyses of the seven accessible records in the Southern Hemisphere have shown inconclusive trends. Since late 1995, surface ozone is measured in situ at "El Tololo", a high-altitude (2200 ma.s.l.) and pristine station in Chile $\left(30^{\circ} \mathrm{S}, 71^{\circ} \mathrm{W}\right)$. The dataset has been recently fully quality controlled and reprocessed. This study presents the observed ozone trends and annual cycles and identifies key processes driving these patterns. From 1995 to 2010, an overall positive trend of $\sim 0.7 \mathrm{ppbdecade}^{-1}$ is found. Strongest trends per season are observed in March and April. Highest mole fractions are observed in late spring (October) and show a strong correlation with ozone transported from the stratosphere down into the troposphere, as simulated with a model. Over the 20 years of observations, the springtime ozone maximum has shifted to earlier times in the year, which, again, is strongly correlated with a temporal shift in the occurrence of the maximum of simulated stratospheric ozone transport at the site. We conclude that background ozone at El Tololo is mainly driven by stratospheric intrusions rather than photochemical production from anthropogenic and biogenic precursors. The major footprint of the sampled air masses is
\end{abstract}

located over the Pacific Ocean. Therefore, due to the negligible influence of local processes, the ozone record also allows studying the influence of El Niño and La Niña episodes on background ozone levels in South America. In agreement with previous studies, we find that, during La Niña conditions, ozone mole fractions reach higher levels than during El Niño conditions.

\section{Introduction}

Tropospheric ozone $\left(\mathrm{O}_{3}\right)$ is a key atmospheric compound that plays an important role in many respects: it acts as a greenhouse gas, which is contributing to radiative forcing of up to $21 \%$ relative to the radiative forcing induced by $\mathrm{CO}_{2}$ (Myhre et al., 2013). Ozone has adverse effects on crop yields and on human health, being an irritating agent and triggering asthma and cardiovascular diseases (Reich and Amundson, 1985; Brook, 2002; Fiscus et al., 2005). Ozone is also a major source of hydroxyradicals and, thereby, influences the oxidative capacity of the atmosphere (Crutzen, 1971; Staehelin et al., 2001).

Various processes determine the amount of ozone in the troposphere: ozone is naturally produced by oxidation of methane, by reaction of oxygen with lightning-induced NO production, as well as by photochemical formation in the presence of volatile organic compounds (VOCs), nitrogen 
oxides $\left(\mathrm{NO}_{x}\right)$, and sunlight (Crutzen, 1971, 1973; Crutzen and Zimmermann, 1991; Winer et al., 1992; Derwent et al., 1998). Thus, changes in ozone precursor emissions which are partly due to anthropogenic activities - considerably influence the tropospheric ozone burden. However, a straightforward attribution of emission changes to ozone trends is challenging due to the highly nonlinear photochemistry, different (VOC- and $\mathrm{NO}_{x}$-limited) ozone production regimes, and also photochemical loss processes (Crutzen, 1971; Sillman and He, 2002). A significant part of tropospheric ozone originates from stratosphere-troposphere transport (STT), also known as stratosphere-troposphere exchange (STE), happening, e.g., in tropopause folds (Holton et al., 1995; Škerlak, 2014; Škerlak et al., 2014; Lefohn and Cooper, 2015). The STE is not evenly distributed over the globe and hotspots of transport of stratospheric ozone into the planetary boundary layer exist in the region of the Rocky Mountains, Tibetan Plateau, Andes (around $30^{\circ} \mathrm{S}$ ), storm tracks, and Indian Ocean ( ̌̌kerlak et al., 2014). Recent modeling studies postulate that the contribution from STE to the tropospheric ozone burden may be as high as $23 \%$ of the net photochemical production (Stevenson et al., 2006; Sudo and Akimoto, 2007). This contribution may change in the future due to climate change and could lead to more than $20 \%$ STE increase (Collins et al., 2003; Hegglin and Shepherd, 2009; Neu et al., 2014).

Ozone sinks include catalytic destruction involving $\mathrm{HO}_{2}$ and photolytic destruction; $\mathrm{O}_{3}$ can also be removed from the atmosphere by dry deposition, wet scavenging, and uptake by vegetation (Galbally, 1968; Stevenson et al., 2006).

The first ozone observations in the atmosphere were performed in the 19th century in Montsouris, Paris (Volz and Kley, 1988). However, regular and geographically distributed measurements have become more established only in the second half of the 20th century. Nowadays, surface ozone observations are widespread and data are available from various data repositories such as the World Data Centre for Greenhouse Gases (WDCGG) of the Global Atmospheric Watch (GAW) programme of WMO or from regional environmental agencies like the European Environment Agency (AirBase), the US Environmental Protection Agency (CASTNET, AQS), and the Acid Deposition Monitoring Network in East Asia (EANET). Currently, observations in the Southern Hemisphere (SH) in general, and in South America in particular, are very sparse (Sofen et al., 2016a, b).

Following Parrish et al. (2012), Oltmans et al. (2013), and Cooper et al. (2014), emissions of anthropogenic volatile organic compound and hydrocarbon emissions have led to a strong rise of ozone production in the last century. In fact, ozone has been generally increasing by up to 3 and $7 \mathrm{ppbdecade}^{-1}$ in the $\mathrm{SH}$ and Northern Hemisphere $(\mathrm{NH})$, respectively, averaged over different time spans (all between 1971 and 2011 and at least averaged over 10 years; see, e.g., Table 1 of Cooper et al., 2014). Thorough research has been undertaken to explain the difference in the trends between the two hemispheres. The more pronounced trend in the NH can possibly be explained by (i) higher precursor emissions than in the SH and (ii) relatively short lifetime of ozone and subsequent lack of transport into the SH. Moreover, trends in the $\mathrm{NH}$ are very different from location to location. Recent work raised the attention to the flattening of the positive trend in NH tropospheric ozone at certain sites, especially at those located in Europe or eastern North America (Cooper et al., 2014). At most stations, this finding can be explained by decreasing nitrogen oxides $\left(\mathrm{NO}_{x}=\mathrm{NO}+\mathrm{NO}_{2}\right)$ emissions in the developed western countries. Such a leveling off is currently not observed in the western United States as $\mathrm{NO}_{x}$ sources in upstream regions such as eastern Asia are still significantly increasing (Cooper et al., 2012). In contrast, the few SH ozone monitoring stations only partly recorded a flattening of the trend (Cooper et al., 2014). These ozone time series show either increasing positive trends (Oltmans et al., 2013; Thompson et al., 2014) or no significant change at all (Oltmans et al., 2013; Cooper et al., 2014). A worldwide map of ozone trends interpolated from the existing surface ozone measurement stations is not yet available. Wespes et al. (2016) recently tried to map ozone mixing ratio trends in the lower troposphere by using remote sensing satellite data from 2008 to 2013. They showed that ozone mixing ratios in the lower troposphere were generally decreasing all over the $\mathrm{SH}$ and in most parts of the NH during this period. However, this trend cannot be generalized as polluted areas of the world still show significant positive ozone trends.

Tropospheric ozone records often show a pronounced seasonal cycle. While in polluted areas a strong photochemically driven summer peak is observed, a spring peak with stratospheric influence dominates in most continental pristine regions (Wang et al., 1998a, b; Monks, 2000). Stations in the marine boundary layer in the SH such as Cape Grim, Australia, rarely reveal a distinct spring peak but rather show a summer peak due to $\mathrm{HO}_{2}$ photochemistry (Ayers et al., 1992; Monks, 2000). Measurements in the SH free troposphere (e.g., La Quiaca, Argentina; 3459 m a.s.1.) show a spring maximum (Barlasina et al., 2013) similar to the $\mathrm{NH}$ ozone time series from unpolluted stations. These findings were more broadly confirmed by Cooper et al. (2014), who, using satellite-measured total column ozone datasets, classified the onsets of the total column ozone (TCO) maxima globally. In general, spring TCO maxima are found rather on the $\mathrm{SH}$, while summer TCO maxima are prominent in the NH. This latter work is in contrast to the results of Monks (2000), who concluded that the spring phenomenon is primarily a NH feature. Wang et al. (1998a) and, more recently, Lin et al. (2015) state that at least some NH spring peaks originate from a combination of ozone-rich stratospheric influx (February-April) and formation by local ozone chemistry (April-June). A recent analysis of the ozone seasonal cycle at northern midlatitudes revealed a shift of these ozone spring peak concentrations backwards by 3 to 6 days per decade (Parrish et al., 2013). They conclude that this fea- 
ture may be explained by changes in atmospheric dynamics, possibly combined with variations in the geographical distribution of the precursor emissions.

At low latitudes, tropospheric ozone levels at remote sites are known to be sensitive to teleconnections like the El Niño/Southern Oscillation (ENSO). For example, Lin et al. (2014) analyzed the seasonal cycle of a long-term ozone dataset from Mauna Loa (MLO, Hawaii), a tropical station in the Pacific. There, long-term springtime ozone observations only marginally increased in the 2000 s whereas fall ozone was observed to significantly augment in the 1990s. Lin et al. (2015) found the cause to be the ENSO, which, by altering SST, convection, and large-scale atmospheric patterns, reduced (augmented) advection of air masses from Asia in spring (fall) during La Niña (El Niño) events. In the extratropics, the opposite is found: springtime ozone levels have increased over time. Lin et al. (2015) explain this discrepancy with ENSO-driven decadal shifts in the atmospheric dynamics, leading to cooling pattern in the eastern Pacific equatorial region. The ENSO-sensitive pattern limits itself not only to tropospheric ozone but also to TCO, as has been shown in Ziemke et al. (2010), who retrieved an independent ENSO index based on TCO anomalies in the pacific region (Ozone ENSO index, OEI).

The GAW ozone network has a satisfactory station coverage over the $\mathrm{NH}$. This is not the case for the $\mathrm{SH}$, where the network is very sparse and additional surface ozone time series are needed to understand the global picture of ozone dynamics. This paper describes a recently quality controlled 20-year surface ozone dataset from "El Tololo", a midlatitudes, subtropical mountain site in Chile, South America, where ozone and a standard set of meteorological variables have been measured since 1995. Recently, the station has been equipped with a new ozone monitor and a $\mathrm{CO}, \mathrm{CO}_{2}$, and $\mathrm{CH}_{4}$ analyzer by Empa (Swiss Federal Laboratories for Materials Science and Technology).

El Tololo is currently the only GAW station in the SH above the marine boundary layer regularly submitting tropospheric ozone data to WDCGG. Therefore, the station provides highly valuable information on the ozone distribution in the unpolluted atmosphere. Gallardo et al. (2000) and Rondanelli et al. (2002) published analyses of the early phase of the ozone record, pointing at particular characteristics of the ozone time series in connection with large-scale Hadley circulation, cutoff lows, and deep troughs or related to transport from the boundary layer.

The main objectives of this study are to characterize the complete time series of this station, which is likely representative of a large domain of the background $\mathrm{SH}$, and to provide insight into the key processes driving the observed variability and trends. Section 2 gives an overview of the measurement station and the instrumentation. In Sect. 3, the data series are presented and interpreted. Finally, we present our conclusions in the last section.

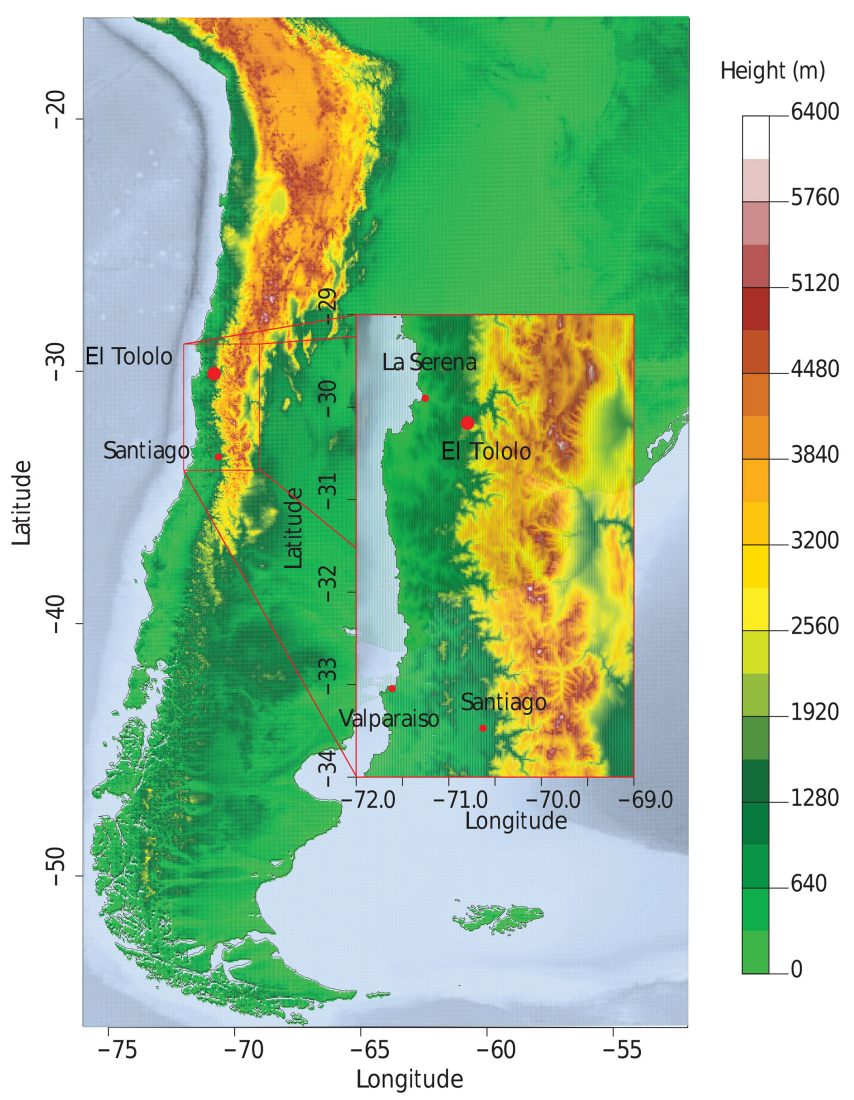

Figure 1. Position of El Tololo, La Serena, Valparaíso, and Santiago de Chile including topographic information. Terrain data source: NOAA ETOPO1, plotted using marmap (Pante and Simon-Bouhet, 2013).

\section{Station characterization}

\subsection{Location}

The atmospheric monitoring station "El Tololo" (TLL) is located in the Coquimbo region at $2200 \mathrm{~m}$ a.s.l., $30^{\circ} 10^{\prime} \mathrm{S}$, $70^{\circ} 47^{\prime} \mathrm{W}, 400 \mathrm{~km}$ north of Santiago de Chile, around $90 \mathrm{~m}$ below the top of the mountain Cerro Tololo. At Cerro Tololo, astronomical telescopes and instruments are operated as the Cerro Tololo Inter-American Observatory (CTIO), which belongs to the US National Optical Astronomy Observatory (NOAO). The Chilean Meteorological Service (Dirección Meteorológica de Chile, DMC) runs the El Tololo station on the CTIO area. The distance from El Tololo to the next bigger cities is $50 \mathrm{~km}$ to the NW (La Serena, Coquimbo) with smaller towns nearby (Vicuña, $20 \mathrm{~km}$ NE; Paiguano, $30 \mathrm{~km} \mathrm{NE}$; Andacollo, $30 \mathrm{~km} \mathrm{SW}$; Ovalle, $60 \mathrm{~km} \mathrm{SW}$; see Fig. 1). Fifteen kilometers north of El Tololo, the Elqui Valley, which is dominated by agricultural activity, is located in a W-E elongation. The population density of this region is low: 17 inhabitants per $\mathrm{km}^{2}$. 


\subsection{Climatology}

Climate at TLL is classified as cool and arid. Between 1995 and 2015, the average temperature was $13.4^{\circ} \mathrm{C}$ (see Fig. S3 in the Supplement) and, in most years, less than $70 \mathrm{~mm}$ of rainfall was registered, which classifies climate as a "desert climate" (BWk) following Köppen climate classification of Geiger (1961) and Kottek et al. (2006). The wind measured at TLL mostly blows from the SSW sector during the summer months (December, January, and February, DJF) and from the NNE sector during the remaining time of the year (see Fig. S4). However, the wind direction data do not necessarily represent the free atmosphere, as the local topography at the station partially obstructs advection from the NW to N sectors. Moreover, turbulent eddies downwind of the mountain top influence the measured wind direction. Kalthoff et al. (2002) described the mesoscale wind regimes affecting the area.

In order to identify the main origin of the air masses arriving at TLL, backward trajectory simulations from the FLEXTRA model (e.g., Stohl et al., 1995), calculated at Empa, were used. The model uses wind fields from the European Centre for Medium-Range Weather Forecasts (ECMWF), and subsequent analysis locates the source of the trajectories in the northwestern to southern sector with some rare events from the north and southeast (see Fig. 2). The influence of air parcels from the northeastern parts of South America is minor since the Andes are efficiently blocking any advection of air masses from this direction. Therefore, local pollution events from the greater Santiago de Chile region are more relevant than large-scale pollution events originating, e.g., from biomass burning in the Amazon region. $71 \%$ of the 10-day-trajectories start at an altitude between 0 and $5000 \mathrm{~m}$, and $10 \%$ of the 10-day-trajectories originate from altitudes higher than $8000 \mathrm{~m}$ (see Fig. S5). The origins of the trajectories follow clearly distinguishable seasonal patterns: during the summer months (DJF), most trajectories originate from south of the station and from the lower troposphere. During the winter months (JJA), more trajectories start north of the station, as the southeastern pacific high shifts to more northern latitudes at that time of the year (e.g., Rahn and Garreaud, 2014). This also explains why trajectories from the upper troposphere are more frequent in JJA compared to DJF $(+50 \%)$, following increased subsidence. The mean air trajectory length is highest during spring time (SON) and lowest during fall (MAM, see Fig. S6).

Being located in the subtropics, TLL is rarely affected by frontal or cyclonic systems. Nevertheless, during spring and summer time (SON, DJF), cutoff lows and troughs from higher latitude may reach subtropical regions, thus influencing the large-scale advection patterns at TLL (Rondanelli et al., 2002) on short timescales. This leads both to advection of polar air masses as well as upward transport of marine boundary layer air potentially polluted by human activities

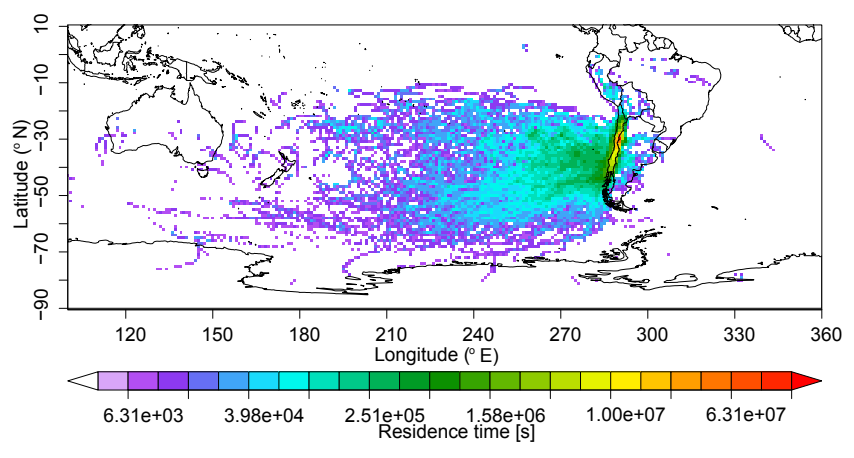

Figure 2. FLEXTRA trajectory footprint from April 2013 to December 2015, originating at El Tololo (TLL), $370 \mathrm{~m}$ above model topography. Color indicates the total residence time of air parcels, summed up over the time period. TLL is marked with a black dot.

in the nearby cities, possibly influencing the chemical composition of the air at TLL.

Apart from meteorological frontal systems, climatological patterns like the ENSO do influence the large-scale origin of air masses arriving at TLL. In Fig. 3, the wind climatology and the change in the wind field during an exemplary strong El Niño (1997-1998) and La Niña (1988-1989) event are shown for austral spring and austral fall (ERA-Interim reanalysis (ERAI), $700 \mathrm{hPa}$ wind, climatology from 1979 to 2015; see Sect. 4.3 for details).

The subtropical Pacific high determines subsidence in the Tololo area year-round, interrupted occasionally by passing fronts or cutoff lows (Fuenzalida et al., 2005). It also drives a low-level jet (LLJ) along the west coast of South America, which peaks in intensity in spring (Garreaud and Muñoz, 2005; Muñoz and Garreaud, 2005). During El Niño (La Niña) years, the Pacific high becomes weaker (stronger), which leads to negative (positive) anomalies in subsidence and coastal southerly winds.

As mentioned earlier, ozone transport due to STE is an important factor of the tropospheric $\mathrm{O}_{3}$ burden particularly in the remote SH. The ERAI climatology shows a "hotspot" of downward transport of stratospheric, ozone-rich air masses above TLL (see Fig. 2 in Škerlak et al., 2014), especially during austral spring and summer. This can most probably only be explained by gravity wave triggering when air parcels originating from the southern pacific region suddenly encounter a strong change in orographic height (Andean barrier, up to $6000 \mathrm{~m}$ a.s.l.). Moreover, the weakening of the subtropical jet stream in DJF favors additional wave breaking, triggering downward transport of ozone through tropopause folds. This potentially leads to a higher burden of tropospheric ozone in DJF. We will discuss this subject more thoroughly later in this work. 

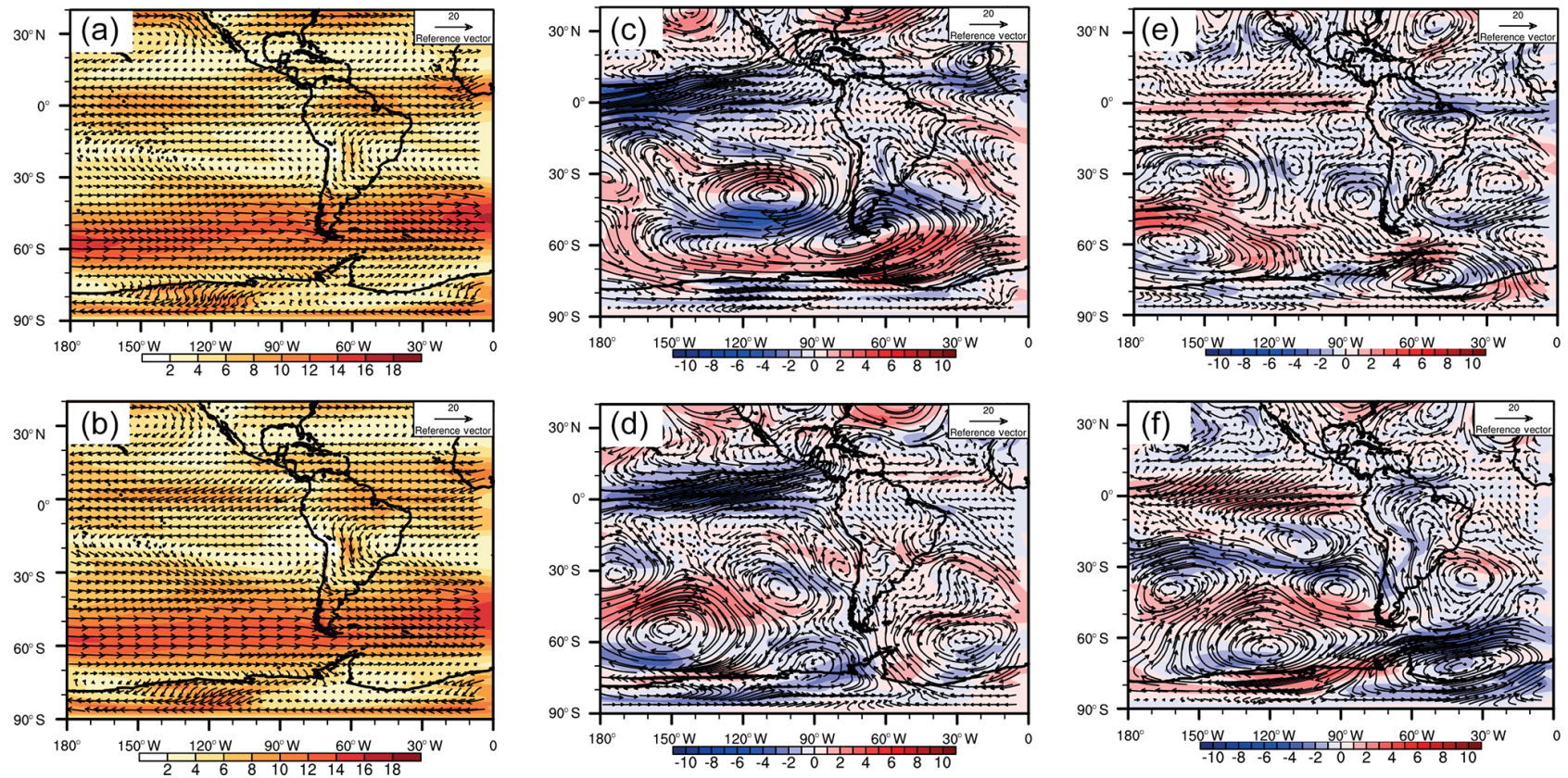

Figure 3. ERAI wind climatology at $700 \mathrm{hPa}$ (a MAM and b SON) and wind change in vector and strength during an exemplary El Niño event (1997-1998) (c MAM and d SON) and a La Niña event (1988-1989) (e MAM and f SON).

\section{Data and methods}

\subsection{Ozone data at El Tololo}

In 1995, TLL has been equipped with an ozone photometer and a set of meteorological sensors. Ozone at TLL is measured by UV absorption with a Thermo Environmental Instruments Inc. TECO 49-003 analyzer. The station is equipped with an external ozonator which allows producing defined levels of ozone to conduct performance checks. Measurements are done continuously and data are recorded on a Campbell Scientific 21X data logger as 15 min averages. Zero and span checks on multiple levels are done twice weekly and once monthly, respectively, to keep track of the background signal and the instrument response. Regularly, the operator visually inspects the recorded data for obvious anomalies.

The TECO 49-003 analyzer measures the UV light absorption in the Hartley band $(220-310 \mathrm{~nm})$ where ozone is a strong absorber. The optical bench is a dual-cell device which is connected to a mercury lamp $(245 \mathrm{~nm})$ as light source. Alternately, one cell is flushed with ozone-free air while the other is simultaneously flushed with sample air. This allows a correction for changes in light intensity and potential interfering species. The TECO 49-003 has a sensitivity of $\pm 1 \mathrm{ppb}$ and a precision of $2 \mathrm{ppb}$. The response time is on the order of $20 \mathrm{~s}$ to reach $95 \%$ of the new signal (TEI, 1992). In September 2010, instrument performance of the analyzer was assessed during the SMN/WMO/GAW 4th Tropospheric Ozone Analyzer Intercomparison at the Servicio
Meteorológico Nacional, Observatorio Central de Buenos Aires, Buenos Aires, Argentina. The instrument passed all checks and a comparison with an ozone traveling standard of the World Calibration Centre for Surface Ozone (WCCEmpa) confirmed the validity of the instrument calibration (see WCC report at http://empa.ch/documents/56101/ 250799/2010_BsAs_RCC-O3.pdf).

In early 2013 , the station was equipped with an additional instrument measuring greenhouse gases (Picarro Inc. G2301 CRDS for $\mathrm{CO}_{2}, \mathrm{CH}_{4}, \mathrm{CO}$, and $\mathrm{H}_{2} \mathrm{O}$ analysis) and a refurbished ozone photometer (Thermo Scientific, TE49c) using the same measurement principle as the TECO 49 , as the latter is reaching the end of its life. The two independent ozone time series agree well. A small systematic offset has been observed which is most likely due to different inlet heights above ground for the two measurement systems. A short overview comparing the overlapping measurements of the two devices is given in the Supplement (Sect. S1, Fig. S1). Figure S7 shows the time series of meteorological parameters.

\subsection{Ozone data used in this study}

In situ ozone data from other surface stations in the GAW network (K-puszta (Hungary), Ushuaia (USH, Argentina), Cape Point (CPT, South Africa), Cape Grim (CGO, Australia), and La Quiaca (LQO, Argentina); see https://gawsis. meteoswiss.ch for more details) were downloaded from the WDCGG (http://ds.data.jma.go.jp/gmd/wdcgg/) and are used for comparison purposes. 
In addition to the surface ozone measurements, ozone sondes are recording valuable information about the vertical ozone distribution in the atmosphere, e.g., within the SHADOZ project since 1998 (Thompson et al., 2007). Frequent data are available from Ascension Island (United Kingdom), Suva (Fiji), Watukosek (Java), Natal (Brazil), La Réunion (France), Pago Pago (American Samoa), San Cristobal (Ecuador), and Irene (South Africa), where sondes have been launched every 2 to 6 days. Additionally, ozone soundings from Easter Island (Rapa Nui, Chile) have been kindly provided by the DMC (P. Velázquez, personal communication, 2016) as the long-term data were not available from any data center yet. The ozone sondes are all equipped with an electrochemical concentration cell (ECC). According to Thompson (2003) the agreement between the sonde and the groundbased measurements lies around 2-7\%.

Model data from two sources are used in this work to study the atmospheric large-scale influences on the local measurements at TLL: (i) an STE climatology from Škerlak et al. (2014) and (ii) wind field climatologies from the ERAI. The STE climatology allows identifying the footprint of a potential ozone contribution from the stratosphere, while the ERAI is used to help understanding the effect of climatic variability associated, for example, with ENSO.

\subsection{Methods}

Prior to the long-term trend analysis, data are rigorously screened to eliminate all data potentially influenced by local pollution. In a first step, values above $55 \mathrm{ppb}$ or below $10 \mathrm{ppb}$ are flagged and visually inspected for outliers, as those data points mostly arise from zero/span checks or local influences (Fig. S2a). In a second step, a further filtering is applied inspired by the well-established approach from Thoning et al. (1989) applied to the long-term $\mathrm{CO}_{2}$ record at Mauna Loa, Hawaii. Adapting their method to ozone and to the conditions at El Tololo, data points with ozone mole fractions experiencing a change of more than $4 \mathrm{ppb}$ from one hour to the next are excluded (Fig. S2b). This value of 4 ppb has been defined as such to avoid too many false positives or negatives during the automatic filtering process in order to minimize the workload during the manual dataset review process. In a third step, a polynomial fit is applied to the nocturnal data (23:0006:00 LT) and data points exceeding twice the standard deviation of all data points of the nocturnal fit computed over one night are excluded (Fig. S2c and d). An example of the effects of this filtering can be seen in the Supplement, Sect. S2. A final visual inspection is performed in order to exclude any periods of sampling problems or local pollution events referenced in the station log books (see Table S1). As well, correction of "false negatives" flagged by the automatic filtering routine can be recovered. Only then are the 15-minute ambient air data averaged to hourly data, hourly averages to daily data, and daily averages to monthly data. The filtering excludes approximately $4.9 \%$ of the available data, indicat- ing the pristine setting of the sampling site with hardly any influence from local pollution sources from the premises' infrastructure.

Trends are computed from filtered, deseasonalized monthly averages. Deseasonalization is done using an additive model (Kendall and Stuart, 1983), separating the seasonal component and the trend from the time series. Significance is estimated by means of a two-sided Student $t$ test at the $5 \%$ significance level except where explicitly noted. In order to make the analysis more robust, all-time ( $24 \mathrm{~h})$, nighttime (22-04 LT), and daytime (11-17 LT) data are analyzed separately. To discern changes in the diurnal and annual cycle, seasonal and monthly means based on hourly data of two periods (1996-2000 and 2011-2015) are computed. Correlation tests are assessed with the Pearson's product moment correlation coefficient, which follows a $t$ distribution.

To discern changes in the annual cycle, daily data have also been investigated. The Huang-Hilbert transform technique was selected to decompose those daily data into intrinsic mode functions (IMF) with the use of ensemble empirical mode decomposition (EEMD; Huang and Wu, 2008; Wu and Huang, 2009). The EEMD allows decomposition of the time series into a residual trend and various oscillating signals representative of variations at seasonal, synoptic, and other timescales. EEMD turned out to be particularly powerful for this time series analysis as it succeeds to mimic the asymmetric seasonal cycle peaking in October (see later), which is rather hard to match with sine-curve fitting. However, EEMD is not a very suitable tool for discontinuous time series (Barnhart et al., 2011), making it less potent when trying to investigate particular seasons individually.

Datasets of daily averages from the other GAW stations do not undergo the filtering process. However, in order to distinguish more easily the time at which seasonal maximum ozone mole fractions occur, a running mean with a window of 4 days is applied to the data, including those of TLL.

Ozone sounding data (see Sect. 3.2) were cumulated per station in order to get annual cycles as follows: for each station, all soundings with valid data were temporally aligned in order to reach data densities of as many days per year as possible, thus creating a small climatology. Multiple values for the same day of the year were averaged. Stations with less than $70 \%$ data coverage in a given year were rejected. Similarly to the surface stations, the annual cycle is smoothed with a running mean (width of filter: soundings with visually homogeneous, regular seasonal cycle of 10 days; soundings with visually irregular seasonal cycles (Macquarie island, Marambio, and Ushuaia) of 20 days) at pressure levels of $1000,900,800,700,600$, and $500 \mathrm{hPa}$ in order to compute the timing of the seasonal ozone maximum for several altitudes.

The dataset used for large-scale stratosphere-totroposphere ozone transport studies (Škerlak et al., 2014) is based on the ERAI data from ECMWF (Simmons et al., 2007). Driven by the wind field of ERAI, Škerlak et 
al. (2014) calculated kinematic trajectories using a threestep iterative Eulerian integration scheme (Sprenger and Wernli, 2015). Trajectories are started on a dense global grid and calculated for $24 \mathrm{~h}$, where only the ones crossing the tropopause are flagged. These flagged trajectories are extended 4 days backward and forward, and those with a residence time in the troposphere shorter than $48 \mathrm{~h}$ are excluded from the climatology. Škerlak et al. (2014) estimated a transport of $6.52 \times 10^{11} \mathrm{~kg}$ of ozone per trajectory $\left(\Delta m_{\mathrm{O}_{3}}\right)$, which is given by the size of the model grid cell. The mass flux $\left(\Delta \mathrm{MF}_{\mathrm{O} 3}\right)$ is then a multiplication of the number of trajectories $(n)$ per unit of time $(t)$ times the mass of ozone transported downwards through a certain model level surface $\left(\Delta m_{\mathrm{O}_{3}}\right)$ :

$\Delta \mathrm{MF}_{\mathrm{O}_{3}} \approx n \cdot t \cdot \Delta m_{\mathrm{O}_{3}}$.

For example, mass fluxes around TLL (see Fig. S8) amount to $8-10 \mathrm{~kg}\left(\mathrm{~km}^{2} \mathrm{~s}\right)^{-1}$; for comparison, the half-morning production of ozone over the whole city of Santiago de Chile $\left(641 \mathrm{~km}^{2}\right)$ on a summer day amounts to around $6680 \mathrm{~kg}(3 \mathrm{~h})^{-1}$ (Elshorbany et al., 2009).

\section{Results and discussion}

The complete available ozone dataset at TLL from 1996 to 2015 is shown in Fig. 4a. There are only a few extended data gaps, which are all documented in the station log book (see Supplement, Table S1). The overall data availability is $87 \%$.

\subsection{Long-term trend analysis}

Time series of the filtered deseasonalized monthly means is shown in Fig. 4b. A highly significant increase of $0.66 \mathrm{ppbdecade}^{-1}$ is found for the entire period from 1996 to 2015 ( $p$ value 0.0008 ). The variability of the filtered deseasonalized monthly means is within $\pm 8 \mathrm{ppb}$.

The deseasonalized ozone time series can be further decomposed using the Huang-Hilbert transform technique. By analyzing the residual, a flattening and a reversal of the trend are observed since 2008 and 2010, respectively (Fig. 4c). Up to September 2010, the EEMD calculation reveals a positive linear trend of $0.67 \mathrm{ppbdecade}^{-1}$, which is in accord to the linear fit. The EEMD calculation reverses after September 2010 , resulting in a negative trend of $-0.41 \mathrm{ppbdecade}^{-1}$. Long-term trends similar to TLL can also be found at other stations in both the SH and the NH. Perennial trend analysis can be found in the literature, e.g., for Cape Point, Mace Head, Cape Grim, Mauna Loa, and western US regions (e.g., Yellowstone National Park, Lassen, and others), and most of them show a distinct increase in ozone mixing ratios up to the millennial years - though mostly larger than at TLL - before showing signs of leveling off (GAW, 2013; Carslaw, 2005; Derwent et al., 2013, 2007; Oltmans et al., 2013; Cooper et al., 2014; Baylon et al., 2015; Lin et al., 2014). This phenomenon is particularly pronounced at certain $\mathrm{NH}$ stations

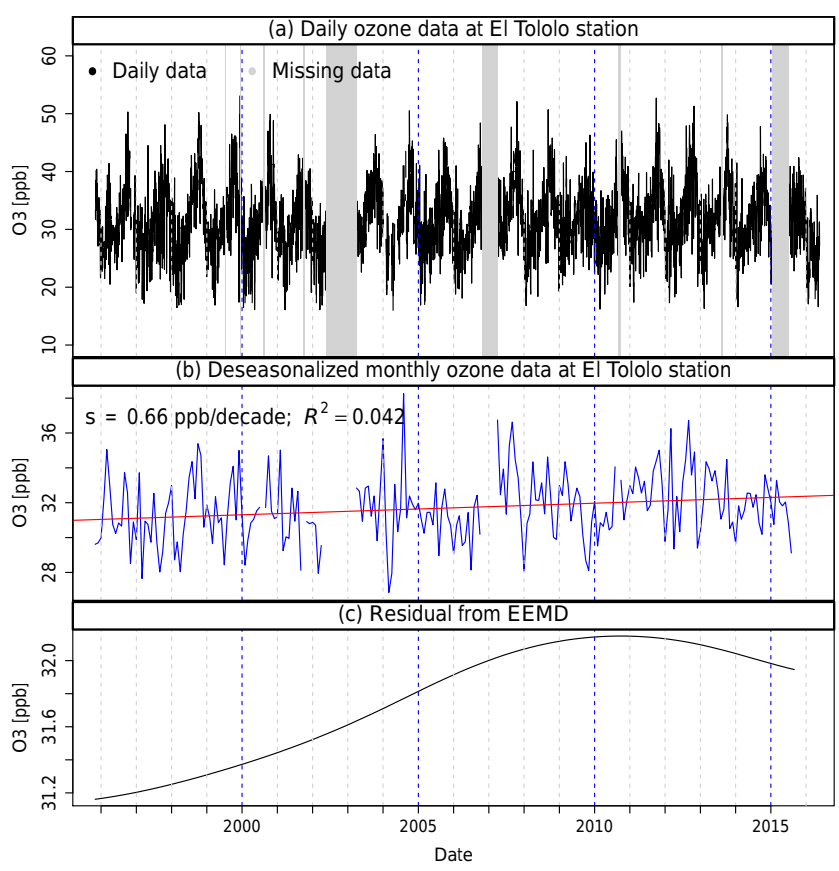

Figure 4. Time series of (a) hourly ozone mole fractions at TLL (black) and data gaps (grey) and (b) deseasonalized monthly means of ozone mole fractions at TLL (blue) with linear fit (red). Slope of the linear fit is $0.66 \mathrm{ppbdecade}^{-1}$; (c) residual trend of the EEMD decomposition.

in Europe and in the western US, as shown in Cooper et al. (2014): global ozone concentrations which have been rising for more than 20 years tend to level off and even reverse quite significantly in those regions since the millennial change. This is primarily due to large-scale changes in $\mathrm{NO}_{x}$ and VOC emissions. In contrast, some western US stations still show signs of growing ozone concentrations, as they are downwind of pollutants from eastern Asia. Those stations, including Mauna Loa (Hawaii), which sample air with origin over the Pacific Ocean, may be partly comparable with the TLL station, which is also sampling air from oceanic origin, although the emissions of pollutants upwind of the western US coast are by far much higher than the emissions at similar longitudes from southern hemispheric regions (e.g., Janssens-Maenhout et al., 2015). NH emissions are moreover prevalent over the whole year (industrial, coal mining, and energy production being the greatest sources) compared to those of the $\mathrm{SH}$, which can be classified as seasonal peaks from biomass burning, originating in Southeast Asia. Considering, however, the influence of ENSO on the ozone time series (see Sect. 4.3), we conclude that air at TLL is certainly influenced at least by a fraction by air masses originating in Southeast Asia and Australia.

Next, the ozone data from TLL will be discussed jointly with data from other stations before the influence of largescale phenomena is discussed in Sect. 4.3. 

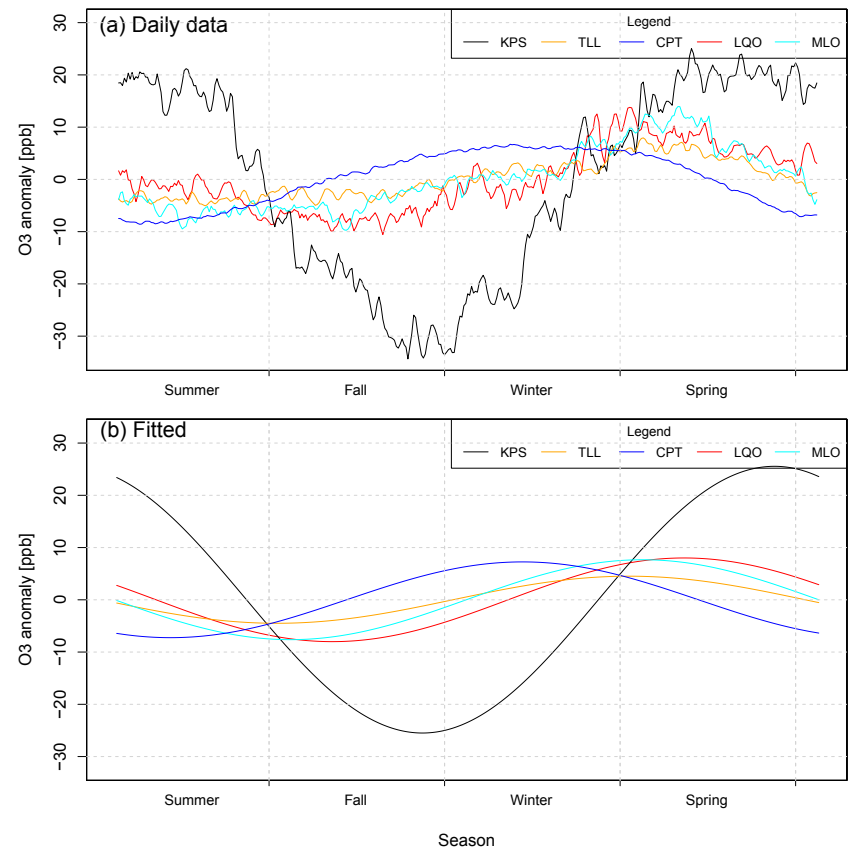

Figure 5. (a) Mean annual cycle of ozone anomalies at different background stations showing a spring maximum (El Tololo, TLL; La Quiaca, LQO; Mauna Loa, MLO), a summer maximum (Kpuszta, KPS), or a summer minimum (Cape Point, CPT). Anomalies are deviations from the annual mean. The $x$ axis shows the season of the year. Northern hemispheric data are shifted by 182 days. (b) Sine fit to the annual cycles shown in (a).

\subsection{Annual cycles of $\mathrm{O}_{3}$ at El Tololo, other ground-based sites, and from ozone sondes}

In the following, the ozone data from TLL and other remote sites will be discussed with respect to the time of the ozone maximum during the year as well as the shape and the amplitude of the annual cycle.

Next to TLL, different monitoring stations in the $\mathrm{NH}$ (Jungfraujoch (JFJ), MLO, KPS, Payerne (PAY), and Vindeln (VDL)) and in the SH (Arrival Heights (ARH), Baring Head (BHD), CPT, CGO, USH, and LQO) were analyzed for comparison. Typical averaged annual cycles of selected available data (reduced to five typical cycles with KPS (summer maximum), TLL, LQO, and MLO (spring maximum), and CPT (winter maximum) for more clarity) are illustrated in Fig. 5a and b, where the annual cycle of NH stations has been shifted by 182 days for comparability purposes to align the seasons for both $\mathrm{NH}$ and $\mathrm{SH}$ stations.

In order to characterize TLL as a certain type of station, a clustering of the 10 stations into characteristic annual cycle categories has first to be done. All investigated ground-based in situ ozone measurements show a maximum in either winter, spring, or summer, mainly for the three following reasons. (i) Winter maxima can be mainly seen in clean marine environments which are primarily driven by ozone depletion due to negative $\mathrm{NO}_{x}$ anomalies and methyl iodide production in summer (Combrink et al., 1995; or Nzotungicimpaye et al., 2014). (ii) Spring maxima are mainly influenced by STE of ozone-rich air, influencing the regional chemical composition of air through dynamic forcing. (iii) Summer maxima are mainly observed at stations influenced by ozone precursor emissions where photochemical production of ozone is the major process driving the annual ozone cycle.

TLL stands as a good example of a station featuring a spring maximum. An in-depth analysis of the drivers for this maximum is given below.

Photochemical ozone production is mainly following the sine-shaped availability of solar radiation, unless there is a strong seasonal variation in the precursors, e.g., due to biomass burning emissions. Dynamic processes such as the north-south movement of the intertropical convergence zone (ITCZ), shifts in synoptic weather patterns, and ozone entrainment by STE can result in less regular patterns, as the time of occurrence of the processes is usually concentrated over a shorter time period. The STE effect at TLL, visible in Fig. S9, smoothly starts in June, reaches a peak in August, and regresses until December, staying at low levels until May. Little to no STE influence is to be expected during the 5 months between January and May (see also Sect. 4.3). This is the reason why ozone concentrations at TLL follow a slightly asymmetric course over the year. Hence, in order to understand the annual cycles of ozone "in three dimensions" at different latitudes in the $\mathrm{SH}$, additional data are needed.

Therefore, ozone soundings from $12 \mathrm{SH}$ remote locations (San Cristobal (SCR), Natal (NTL), Java (JVA), Ascension Island (ASC), Samoa (SMA), Fiji (FJI), La Réunion (RNO), Irene (IRN), Rapa Nui (RAP), Macquarie Islands (MAQ), Ushuaia (UHA), and Marambio (MAR)) have been analyzed. In Fig. 6, a compilation of our analysis of both soundings and ground measurements is illustrated on an $x-y$ diagram.

Ozone maxima are generally shifting to later times in the year with increasing altitude; i.e., peaks in the annual cycle at $500 \mathrm{hPa}$ occur later than the peaks in the annual cycle at $1000 \mathrm{hPa}$ (see Fig. 6). This can to a great extent be explained by the location of the soundings, which are all launched in a marine environment. As we have learned before, in most marine surface ozone time series a winter maximum prevails (around the days of the year 180-220). An ascending sounding will first sample air that is influenced by photochemistry in the marine boundary layer. Thus, the higher a station is above sea level, the larger is the share of stratospheric input of ozone. At high altitudes, peak concentrations of ozone are therefore shifted towards later in the year. However, this picture is perturbed by the fact that (i) north of $25^{\circ} \mathrm{S}$, little to no STE occurs, and (ii) the solar cycle is weak north of $10^{\circ} \mathrm{S}$. There, interhemispheric mixing explains the late maximum. This process allows some of the NH pollutants to penetrate into the SH across the ITCZ. The ITCZ is also located in a region where biomass burning prevails all year long, leading to a very efficient upward transport of pollutants up to 


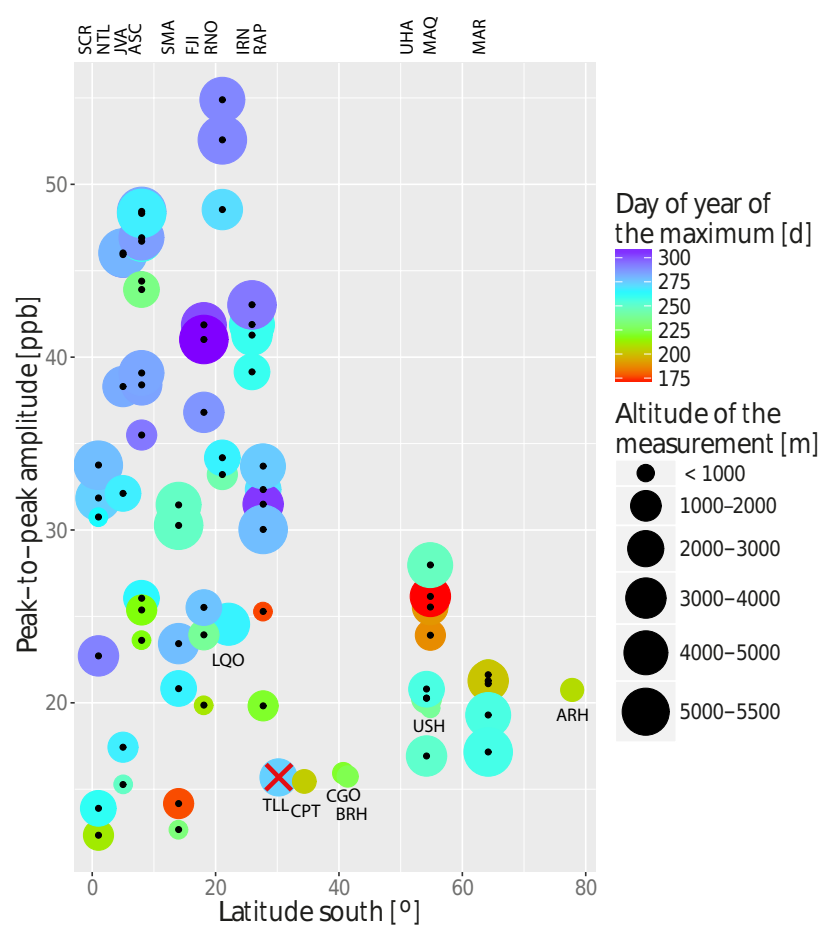

Figure 6. Composite plot showing the different southern hemispheric ozone measurements (SHADOZ and WOUDC network and ground-based in situ data): the $x$ axis shows the southern latitude and the $y$ axis represents the delta between the maximum and the minimum of the annual cycle ("peak-to-peak amplitude"). The size of the points represents the height of the station (ground based) or of the ozone sonde measurement (SHADOZ and WOUDC). The colors depict the day of year when the maximum of the annual cycle is reached. Points with a black spot illustrate sonde measurements. TLL can be seen at $30^{\circ} \mathrm{S}$ and an amplitude of $15 \mathrm{ppb}$.

the tropopause. Following the position of the ITCZ, the most intense ozone production via the $\mathrm{NO}_{x}-\mathrm{HO}_{x}-\mathrm{VOC}$ cycle occurs late in the year. Therefore, we would expect that the maximum shifts from a summer maximum at the equator to a spring maximum at high latitudes.

This hypothesis is further supported by a majority of the soundings (see Fig. 6). Especially for soundings made from $25^{\circ} \mathrm{S}$ southward down to the polar regions, a clear gradient from late maxima to earlier maxima is recognizable (shift from darker to brighter blues). This observation applies not only to soundings but also to ground-based measurements. A trend to earlier maxima is observed from LQO to ARH, although a smoother grading (more stations) would be beneficial to solidify our hypothesis. When classifying TLL, which reaches maximum values around mid-October, it can be noticed that the timing is a bit later than one would expect from extrapolating the ozone sonde measurements, as it is a continental station. Maximum concentrations at CPT, CGO, BRH, $\mathrm{USH}$, or ARH are reached far earlier, mainly due to (i) the marine influence at the stations and (ii) the lack of stratospheric influence down to the surface.

The annual cycle at TLL can best be compared to sonde data taken at similar latitude and height. This is fulfilled best by RNO and FJI. A far weaker peak-to-peak amplitude is found at the surface station TLL (see Fig. 6) than in the free atmosphere. Part of this difference can be explained by the origin of air masses, which is dynamically driven. Focusing on the soundings at Rapa Nui (RAP), during the summer and fall months, a strong high-pressure system with center over the island limits the advection of pollutants from the west, hindering photochemical production of ozone. Later in the season, the high-pressure system moves slightly eastward, allowing transport of air masses from the northwest (Oceania) towards the southern Pacific and, therefore, advecting biomass burning pollutants from Southeast Asia and Oceania via the zonal wind field. In contrast, the sampled air mass at TLL is to a greater part pristine (see above), preventing strong photolytic ozone production in summer.

\subsection{Large-scale influences at TLL}

There are several large-scale processes which potentially impact either short-term or long-term ozone variations at TLL. These factors include large-scale advection of air masses either via the subtropical jet or via potential vorticity cutoffs from the polar jet region, STE of ozone-rich air from the stratosphere, as well as pattern changes in tropical up- or downwelling. The impact of these different elements not only vary over the course of a day (storm-scale) or of a year (seasonal cycles) but may also oscillate over timescales of 2 to 7 years, following teleconnections and large-scale oscillations from features like the quasi-biennial oscillation (QBO) or ENSO.

All these influences are visible in the different ozone data products from TLL. We initially focus on the changes in the mean annual cycle of ozone over time and, based on this, elaborate further on the timing of the maximum and on the shape of the cycle. We conclude this section with a short overview of the observed short-term variations (week scale) including a possible interpretation for those findings.

First, two mean seasonal cycles for two 5-year periods, one at the beginning of the measurements (1996-2000) and the other one in the recent past (2011-2015), were analyzed for potential differences. In Fig. 7, the monthly means, with the upper 95th and the lower 5th percentiles including associated uncertainties, are presented. Table 1 summarizes the findings in numbers. The two periods show a very similar annual cycle. However, there are subtle differences: especially in austral fall (February-March), the 5th percentile, mean, and 95th percentile increased remarkably from the first to the second period. Among the three curves, the 5th percentile shows the most persistent increase from February up to June in the more recent period. For the other months of the year, changes are minor except for October, where 2011-2015 show slightly 
Table 1. Seasonal linear trends of ozone (ppbdecade ${ }^{-1}$ ) at TLL for (a) all-day data (00:00-24:00 UTC), (b) nighttime data from 22:00 to 04:00, and (c) daytime data from 11:00 to 17:00. Significant trends are labeled with ${ }^{\mathrm{a}}(95 \%)$ or ${ }^{\mathrm{b}}(90 \%)$, and standard error is shown as \pm .

\begin{tabular}{lrrrrrrrr}
\hline Time of day/season & DJF & $p$ value & MAM & $p$ value & JJA & $p$ value & SON & $p$ value \\
\hline All & $-0.1 \pm 0.05$ & 0.619 & $1.6^{\mathrm{a}} \pm 0.06$ & 0.0353 & $0.2 \pm 0.04$ & 0.855 & $0.1 \pm 0.07$ & 0.881 \\
Nighttime & $0.03 \pm 0.06$ & 0.843 & $1.8^{\mathrm{a}} \pm 0.07$ & 0.0271 & $0.3 \pm 0.04$ & 0.745 & $0.1 \pm 0.07$ & 0.821 \\
Daytime & $-0.4 \pm 0.05$ & 0.231 & $1.2^{\mathrm{b}} \pm 0.06$ & 0.0909 & $0.1 \pm 0.01$ & 0.866 & $0.1 \pm 0.06$ & 0.802 \\
\hline
\end{tabular}

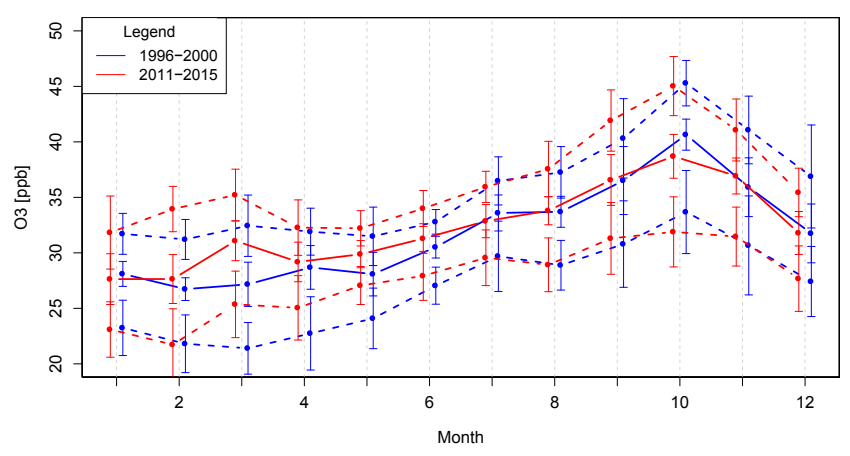

Figure 7. Mean annual cycles of ozone mole fraction (1996-2000 and 2011-2015) showing mean, upper 95th percentile, and lower 5 th percentile. For better readability, the monthly means for both periods have been shifted by \pm 6 days.

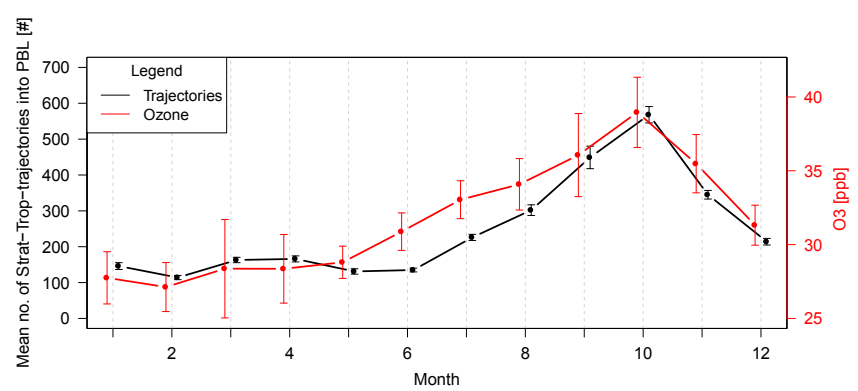

Figure 8. Mean annual cycle over 19 years (1996-2015) of ozone at TLL and of trajectories indicating STE above TLL. For better readability, the monthly means for both variables have been shifted by \pm 6 days.

lower values of $\mathrm{O}_{3}$. The annual cycle and some of the differences between the two periods are mainly driven by the annual cycle of ozone-STE mass flux (see Figs. 8 and S9). However, the increase of ozone mole fractions from March to May cannot be explained by STE only, as at that time ozoneSTE mass flux shows negative anomalies (Fig. S9). Here, three other factors, like QBO or ENSO, change in largescale dynamics and precursor species have to be taken into account.

i. As Neu et al. (2014) showed, positive QBO shear and the multivariate ENSO index (MEI) lead to increased stratospheric air circulation, negative upper troposphere ozone anomalies (due to upwelling of relatively ozone- depleted air), and therefore potentially decreased ozoneSTE activity in the sub- and extratropics. Doherty et al. (2006) and Sekiya and Sudo (2012) explained the decrease in total column ozone found in the eastern $\mathrm{Pa}$ cific region during El Niño conditions with a decrease in $\mathrm{NO}_{x}$ production due to a decrease in lightning activity. The ozone anomalies at TLL and the MEI show significant correlations especially in September-October (correlation of -0.78), and the annual cycles of ozone during El Niño years and La Niña years indeed show significantly different values especially in austral fall and spring (Fig. 10). During La Niña events, ozone levels reach higher values - especially from September to November - than during El Niño events. Figure S10 illustrates that the 1996-2000 period not only had a weak positive correlation (correlation of 0.28 ) of both (QBO shear/ME) indexes but also had one single strong El Niño event lasting nearly 2 years, possibly leading to a decreased ozone-STE burden in 1997-1998. The second, later period showed nearly no in-phase correlation of MEI and QBO shear index (correlation of -0.04) and no significant El Niño event.

ii. The subtropical jet has to be considered as contributing factor to the MAM anomaly in the 2011-2015 period. We assume that with the broadening of the Hadley cell (HC; Choi et al., 2014; Nguyen et al., 2013), the extratropical jet, moving to higher latitudes, increasingly advected more polluted air from Southeast Asia, e.g., in the form of peroxyacetyl nitrate (PAN; Jiang et al., 2016), during this period of the year, when biomass burning prevails (e.g., Streets et al., 2003). More work has to be done to confirm this theory, e.g., using satellite measurements, as this would go beyond the scope of this work.

iii. An increase of biomass burning in Southeast Asia (e.g., Shi and Yamaguchi, 2014; Verma et al., 2015) and Australia (Cooper et al., 2014) with subsequent eastward transport of ozone precursors could also explain the positive anomaly in MAM in the 2011-2015 period, as the northward migration of the ITCZ during this time of the year starts to allow effects of $\mathrm{NH}$ emissions to be seen in the $\mathrm{SH}$ and prevailing westerly conditions (see Fig. 2) exclude any sensitivity of ozone mole fractions at TLL to emissions on the South American continent. 
At most, the ozone increase may originate from regional pollution from the La Serena region, which - in fall - may get transported upwards due to the PBL height and occasional support by frontal systems. This latter assumption remains, however, hypothetical. A confirmation would require high-resolution numerical simulations to resolve the transport in the mountainous terrain of TLL.

In summary, we conclude that the annual cycle is mostly driven by STE from June to January. From February to April, however, the broadening of the $\mathrm{HC}$ with subsequent transport of pollutants from Southeast Asia, the contrast to El Niño dominated (1996-2000) versus average years (20112015), and the increase in precursor species in Southeast Asia are the best explanations for the positive ozone anomaly in the more recent period. From Table 1, we conclude furthermore that, in general, differences between nighttime and daytime trends are very low, which indicates that TLL is a very good background station with similar ozone levels under free-tropospheric conditions and under planetary boundary layer (PBL) influence. Mean ozone mole fractions at TLL only vary between 32.5 and $31.0 \mathrm{ppb}$ during day and night, while other stations located near greater cities (e.g., eastern US; Bloomer et al., 2010) report up to $50 \mathrm{ppb}$ peak differences between nighttime and daytime. This finding is most probably attributed not only to the remote location, far away from pollutant sources, but also to the high altitude located above the PBL.

Regarding the 2-month lag between the recent maximum of STE ozone mass flux and the recent maximum of ozone mixing ratio in Figs. 7 vs. S9, we explain this delayed response of ozone to STE by the following mechanisms: (i) a certain amount of time is needed to equally distribute ozone stemming from STE in the lower troposphere (e.g., titration of $\mathrm{NO}_{x}$ and $\mathrm{HO}_{x}$ residing in the atmosphere) in order to reach chemical equilibrium; and (ii) deep convection underestimation as well as seasonal cycle uncertainties within the ERAI dataset (Škerlak et al., 2014) lead to doubts concerning the exact onset of ozone-STE mass flux maximum around the cordillera.

Concerning the timing of the maximum, Fig. 8 shows a strong correlation (correlation of 0.89 ) between the mean annual cycle of STE trajectories (Škerlak, 2014) and of the ozone concentration. The two parameters show a strikingly similar pattern, indicating that STE may be a strong driver for $\mathrm{O}_{3}$. Note that the "mass flux into the PBL" illustrated in Fig. S9 shows a slightly earlier peak occurrence than the number of "STE trajectories". Another indication for the coupling of $\mathrm{O}_{3}$ concentration and STE is a coherent shift in the maximum of these quantities over the observation period towards an earlier occurrence in the year. This is illustrated in Fig. 9. For calculation, a 4-year sliding window of daily data was defined and run over all data between 1996 and 2015. Then, an empirical mode decomposition was done (Huang

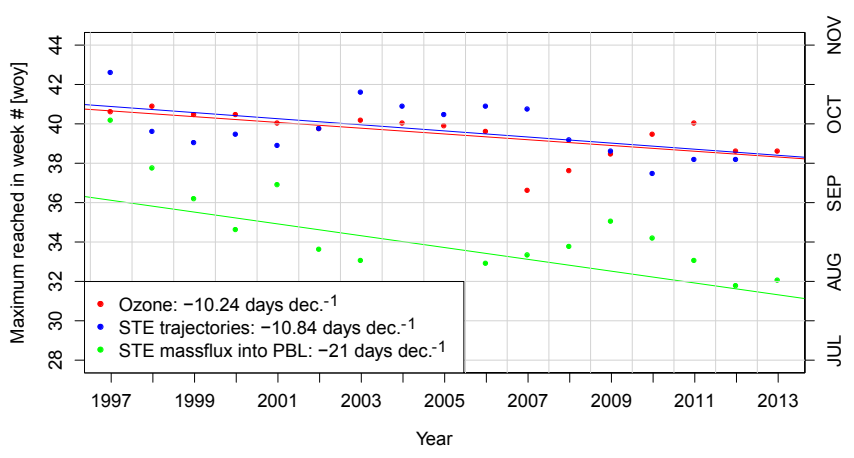

Figure 9. Time of year for which the maximum of ozone (red), STE trajectories (blue), and STE mass flux into the PBL (green) are reached. A 4-year sliding window of daily data was applied. Average values for the years 1996-1999 are shown as the data point at the end of December 1997, 1997-2000 at the end of December 1998, and so forth, until years 2012-2015, which are shown as data point at the end of December 2013.

and Wu, 2008; Wu and Huang, 2009). Out of the Hilbert periodogram, the IMF resembling the most to an annual cycle is selected and the IMF data points are extracted. The latter are averaged to get an average of IMF over the 4-year window. Finally, the day-of-year matching the maximum value of the IMF is extracted. For the ozone time series, a regression of -10 days per decade was calculated. For STT, an even larger trend of -11 or -21 days per decade was obtained for the maximum number of trajectories of stratospheric origin and for the mass flux into the PBL, respectively. Note that the regression is only poorly visible in Fig. 7, where data are aggregated in monthly bins and a comparison of three different percentiles of 5-year monthly averages, instead of absolute maximal values, is shown.

This shift in the seasonal cycle to earlier times in the year has already been presented in other studies for other locations (Parrish et al., 2013; Lin et al., 2014). For instance, spring peaks are observed in the $\mathrm{NH}$ to regress with a rate of 3-14 days per decade (Parrish et al., 2013). Parrish et al. (2013) also suggest that the relative contribution from the stratosphere may at least partly explain the shift in the annual cycle at high-altitude stations in the NH like Jungfraujoch, being located at $3580 \mathrm{~m}$ a.s.l. However, a conclusive explanation for this shift of the seasonal cycle remains missing. Schnell et al. (2016) recently suggested that future climate change will shift the maximum of the ozone seasonal cycle to earlier in the year, but they did not provide any clear explanation for this phenomenon.

Considering the short-term variations, it is known from previous studies that a (anti)correlation between ozone and relative humidity exists at TLL, but only in very specific cases. Gallardo et al. (2000), analyzing the first years of data collected at Tololo, found such an anticorrelation between ozone and water vapor in summer in connection with upslope transport of boundary layer air associated with a ther- 


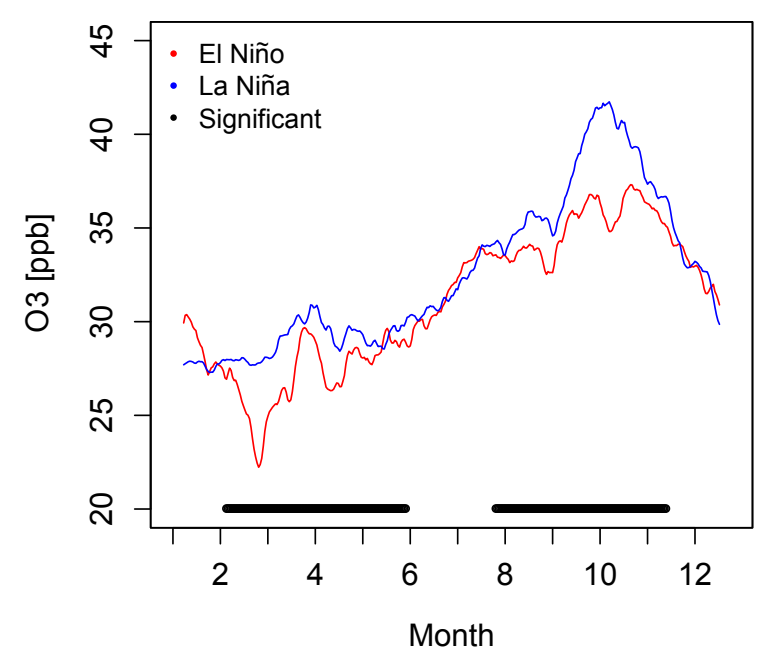

Figure 10. Computed annual cycle of $\mathrm{O}_{3}$ mole fractions at TLL in daily resolution during El Niño days (NINO3.4 Index $>0.5$, total 1914 days between December 1995 and December 2015) and La Niña days (NINO3.4 Index $<-0.5$, total 2330 days between December 1995 and December 2015). Black lines show significant differences between the two curves. NINO3.4 data are derived from daily index reconstructions from SST OI v2 $1 / 4^{\circ}$ data by NOAA.

mally driven circulation. Rondanelli et al. (2002) investigated the effect of troughs associated with a frontal zone passing over TLL and classified their observations in two categories: wet and dry events. During wet events, relatively humid air from the PBL is advected to TLL and, shortly after regression of relative humidity, ozone rises rapidly. During dry events, ozone rises, but relative humidity stays at normal, dry levels or drops even further. Carbon monoxide, a good PBL pollutant and hence an optimal tracer, has been measured in TLL since April 2013. Therefore, the dependence of CO and ozone was investigated. This analysis revealed a significant correlation (not shown) in rare, specific episodes, during which less-pristine air from the PBL - originating from the La Serena, Valparaíso, and Santiago regions - reaches TLL. Those events were not always associated with low potential vorticity values (PV streamer, reconstructed from ERAI data, not shown) or frontal zones, but some of them were. This confirms the finding of Rutllant et al. (2013), who, during the VOCALS-REx campaign, found a persistent, regular southwesterly advection via thermals, able to transport air masses in the afternoon from the marine region into the Andes, which would allow inbound transport of slightly more polluted air masses to TLL. An in-depth analysis of CO-O correlations over several years may be promising to provide more robust conclusions. However, the $\mathrm{CO}$ time series is still limited in time and an extended study would go beyond the scope of the paper.

\section{Conclusions}

The 20-year-long surface ozone time series of El Tololo, Chile (TLL), has been presented and analyzed. It was characterized and put into a global context with the help of STE climatology, trajectory analysis, surface ozone data from other stations, as well as ozone soundings. The analysis shows that El Tololo represents a remote measuring site in a pristine setting, which rarely gets influenced by local pollution, and thus represents an excellent remote GAW station. An indication of this is the relatively small amplitude of the diurnal cycle, even in summer.

The following list summarizes the most important conclusions:

- Only a few data gaps exist in the 20-year-long ozone dataset.

- A positive trend of $+0.66 \mathrm{ppbdecade}^{-1}$ is found up to recent years, which gets weaker from 2010 on and possibly reverses in 2011.

- Over the entire period, the strongest increase in ozone concentrations is observed in austral fall and the strongest decrease in austral summer. This most probably is related to different origins of the air masses and to an increase in precursor species over Southeast Asia.

- In general, the average annual cycle at TLL is dominated by peak concentrations in late spring, followed by a sharp decrease in late winter to early fall, correlating with the shape of average annual STE. TLL can, therefore, be mainly classified as a STE-influenced station, in contrast to stations that are in the marine boundary layer or significantly influenced by anthropogenic pollution.

- Characterizing the TLL dataset with the help of ozone soundings makes it possible to see that the freetropospheric influence is very strong compared to other stations.

- The maximum ozone concentrations were reached around week 41 (early October) in 1996 and have been retrograding since; recently, maximum concentrations are reached around week $38\left(-10\right.$ days decade $\left.^{-1}\right)$. This is attributed to a retrogradation in the same magnitude of the maximum in the ST mass flux into the PBL $\left(-21\right.$ days decade $\left.^{-1}\right)$ and of the number of STE trajectories around El Tololo $\left(-11\right.$ days decade $\left.{ }^{-1}\right)$.

- The ozone concentrations at El Tololo are sensitive to the ENSO. Over the entire year, ozone concentrations are higher during La Niña conditions than during El Niño conditions, especially in late austral spring. This is related to large-scale atmospheric circulation anomalies over the Pacific, changing the strength of the tropical upwelling and coming along with less $\mathrm{NO}_{x}$ production by lightning and changing circulation patterns. 
While many aspects of the $\mathrm{O}_{3}$ time series are well explained, two observations remain unclear and may be elucidated with the help of regional and a global modeling studies. Firstly, the origin of the retrogradation of the timing of ozone-STE maximum is yet unclear. Our hypothesis is that large-scale gravity wave momentum transport has changed over years due to changing tropopause height. Secondly, different ozone trends for different seasons (austral fall versus austral summer) are observed. While part of it can be explained with an increase in precursor species during the biomass burning season over Southeast Asia, we postulate that a second explanation that polluted air masses from the greater Santiago area are transported northwards up to La Serena, where the local wind systems (Elqui Valley wind) transports the plume up to El Tololo. This process has been confirmed by a short preliminary study with a regional model. At least 1 year of high-resolution regional model results is required to be able to confirm or reject this hypothesis.

Data availability. The data product of El Tololo are available on the WDCGG web page free of charge (http://ds.data. jma.go.jp/gmd/wdcgg/cgi-bin/wdegg/download.cgi?index= TLL330S00-DMC\&param=201412030001\&select=inventory)

\section{The Supplement related to this article is available online at doi:10.5194/acp-17-6477-2017-supplement.}

Competing interests. The authors declare that they have no conflict of interest.

Acknowledgements. We acknowledge the support of the Federal Office of Meteorology and Climatology MeteoSwiss through the project Capacity Building and Twinning for Climate Observing Systems (CATCOS) Phase 2, contract no. 81025332, between the Swiss Agency for Development and Cooperation (SDC) and MeteoSwiss. Moreover, we would like to express our gratitude towards Michael Sprenger and Bojan Skerlak, who both advised us how to use their ozone-STE climatology. As well, we thank Dr. Stephan Henne for his support concerning the FLEXTRA datasets and Dr. Dominik Brunner for his valuable comments. Laura Gallardo is grateful for the support of FONDAP 15110009. We would also like to thank the two anonymous reviewers and the editor, Jason West, for their detailed and helpful comments.

Edited by: J. West

Reviewed by: two anonymous referees

\section{References}

Ayers, G. P., Penkett, S. A., Gillet, R. W., Bandy, B., Galbally, I. E., Meyer, C. P., Elsworth, C. M., Bentley, S. T., and Forgan, B. W.: Evidence for photochemical control of ozone concentrations in unpolluted marine air, Nature, 360, 446-449, doi:10.1038/360446a0, 1992.

Barlasina, M. E., Carbajal Benitez, G., Copes, G., Demasi, M., and Cupeiro, M.: Estudio del ozono troposférico en tres observatorios de la red de medición del servicio meteorológico nacional argentina, Proceedings CONGREMET XI, Mendoza, 29 May1 June 2012, available at: http://www.congremet.prmarg.org/ upload/barlasinamaelena.pdf (last access: 20 May 2017), 2013.

Barnhart, B. L., Nandage, H. K. W., and Eichinger, W.: Assessing Discontinuous Data Using Ensemble Empirical Mode Decomposition, Advances in Adaptive Data Analysis, 03, 483-491, doi:10.1142/s179353691100091x, 2011.

Baylon, P., Jaffe, D. A., Wigder, N. L., Gao, H., and Hee, J.: Ozone enhancement in western US wildfire plumes at the Mt. Bachelor Observatory: The role of $\mathrm{NO}_{x}$, Atmos. Environ., 109, 297-304, doi:10.1016/j.atmosenv.2014.09.013, 2015.

Bloomer, B. J., Vinnikov, K. Y., and Dickerson, R. R.: Changes in seasonal and diurnal cycles of ozone and temperature in the eastern U.S, Atmos. Environ., 44, 2543-2551, doi:10.1016/j.atmosenv.2010.04.031, 2010.

Brook, R. D.: Inhalation of Fine Particulate Air Pollution and Ozone Causes Acute Arterial Vasoconstriction in Healthy Adults, Circulation, 105, 1534-1536, doi:10.1161/01.CIR.0000013838.94747.64, 2002.

Carslaw, D. C.: On the changing seasonal cycles and trends of ozone at Mace Head, Ireland, Atmos. Chem. Phys., 5, 34413450, doi:10.5194/acp-5-3441-2005, 2005.

Choi, J., Son, S.-W., Lu, J., and Min, S.-K.: Further observational evidence of Hadley cell widening in the Southern Hemisphere, Geophys. Res. Lett., 41, 2590-2597, doi:10.1002/2014GL059426, 2014.

Collins, W. J., Derwent, R. G., Garnier, B., Johnson, C. E., Sanderson, M. G., and Stevenson, D. S.: Effect of stratospheretroposphere exchange on the future tropospheric ozone trend, J. Geophys. Res., 108, 8528, 10.1029/2002JD002617, 2003.

Combrink, J., Diab, R. D., Sokolic, F., and Brunke, E. G.: Relationship between surface, free tropospheric and total column ozone in two contrasting areas in South Africa, Atmos. Environ., 29, 685-691, doi:10.1016/1352-2310(94)00313-A, 1995.

Cooper, O. R., Gao, R. S., Tarasick, D., Leblanc, T., and Sweeney, C.: Long-term ozone trends at rural ozone monitoring sites across the United States, 1990-2010, J. Geophys. Res., 117, 19902010, doi:10.1029/2012JD018261, 2012.

Cooper, O. R., Parrish, D. D., Ziemke, J., Balashov, N. V., Cupeiro, M., Galbally, I. E., Gilge, S., Horowitz, L., Jensen, N. R., Lamarque, J. F., Naik, V., Oltmans, S. J., Schwab, J., Shindell, D. T., Thompson, A. M., Thouret, V., Wang, Y., and Zbinden, R. M.: Global distribution and trends of tropospheric ozone: An observation-based review, Elementa, 2, 000029, doi:10.12952/journal.elementa.000029, 2014.

Crutzen, P.: A discussion of the chemistry of some minor constituents in the stratosphere and troposphere, Pure Appl. Geophys., 106, 1385-1399, doi:10.1007/bf00881092, 1973. 
Crutzen, P. J.: Ozone production rates in an oxygen-hydrogennitrogen oxide atmosphere, J. Geophys. Res., 76, 7311-7311, doi:10.1029/JC076i030p07311, 1971.

Crutzen, P. J. and Zimmermann, P. H.: The changing photochemistry of the troposphere, Tellus B, 43, 136-151, doi:10.1034/j.1600-0889.1991.t01-1-00012.x, 1991.

Derwent, R. G., Jenkin, M. E., Saunders, S. M., and Pilling, M. J.: Photochemical ozone creation potentials for organic compounds in northwest Europe calculated with a master chemical mechanism, Atmos. Environ., 32, 2429-2441, doi:10.1016/S13522310(98)00053-3, 1998.

Derwent, R. G., Simmonds, P. G., Manning, A. J., and Spain, T. G.: Trends over a 20-year period from 1987 to 2007 in surface ozone at the atmospheric research station, Mace Head, Ireland, Atmos. Environ., 41, 9091-9098, doi:10.1016/j.atmosenv.2007.08.008, 2007.

Derwent, R. G., Manning, A. J., Simmonds, P. G., Spain, T. G., and O'Doherty, S.: Analysis and interpretation of 25 years of ozone observations at the Mace Head Atmospheric Research Station on the Atlantic Ocean coast of Ireland from 1987 to 2012, Atmos. Environ., 80, 361-368, doi:10.1016/j.atmosenv.2013.08.003, 2013

Doherty, R. M., Stevenson, D. S., Johnson, C. E., Collins, W. J., and Sanderson, M. G.: Tropospheric ozone and El Niño-Southern Oscillation: Influence of atmospheric dynamics, biomass burning emissions, and future climate change, J. Geophys. Res., 111, D19304, doi:10.1029/2005JD006849, 2006.

Elshorbany, Y. F., Kleffmann, J., Kurtenbach, R., Rubio, M., Lissi, E., Villena, G., Gramsch, E., Rickard, A. R., Pilling, M. J., and Wiesen, P.: Summertime photochemical ozone formation in Santiago, Chile, Atmos. Environ., 43, 6398-6407, doi:10.1016/j.atmosenv.2009.08.047, 2009.

Fiscus, E. L., Booker, F. L., and Burkey, K. O.: Crop responses to ozone: Uptake, modes of action, carbon assimilation and partitioning, Plant Cell Environ., 28, 997-1011, doi:10.1111/j.13653040.2005.01349.x, 2005.

Fuenzalida, H. A., Sánchez, R., and Garreaud, R. D.: A climatology of cutoff lows in the Southern Hemisphere, J. Geophys. Res., 110, D18101, doi:10.1029/2005JD005934, 2005.

Galbally, I.: Some Measurements of Ozone Variation and Destruction in the Atmospheric Surface Layer, Nature, 218, 456-457, doi:10.1038/218456a0, 1968 .

Gallardo, L., Carrasco, J., and Olivares, G.: An analysis of ozone measurements at Cerro Tololo $\left(30^{\circ} \mathrm{S}, 70^{\circ} \mathrm{W}\right.$, 2200 m.a.s.1.) in Chile, Tellus B, 52, 50-59, doi:10.1034/j.16000889.2000.00959.x, 2000.

Garreaud, R. D. and Muñoz, R. C.: The Low-Level Jet off the West Coast of Subtropical South America: Structure and Variability, Mon. Weather Rev., 133, 2246-2261, doi:10.1175/mwr2972.1, 2005

GAW: GAW Report No. 209: Guidelines for Continuous Measurements of Ozone in the Troposphere, WMO and GAW, WMONo. 1110, 82 pp., 2013.

Geiger, R.: Überarbeitete Neuausgabe von Geiger, R: KöppenGeiger/Klima der Erde, Wandkarte 1: 16 Mill., Klett-Perthes, Gotha, 1961.

Hegglin, M. I. and Shepherd, T. G.: Large climate-induced changes in ultraviolet index and stratosphere-to-troposphere ozone flux, Nat. Geosci., 2, 687-691, doi:10.1038/ngeo604, 2009.
Holton, J. R., Haynes, P. H., McIntyre, M. E., Douglass, A. R., Rood, R. B., and Pfister, L.: Stratosphere-troposphere exchange, Rev. Geophys., 33, 403-403, doi:10.1029/95RG02097, 1995.

Huang, N. E. and Wu, Z.: A review on Hilbert-Huang transform: Method and its applications to geophysical studies, Rev. Geophys., 46, RG2006, doi:10.1029/2007RG000228, 2008.

Janssens-Maenhout, G., Crippa, M., Guizzardi, D., Dentener, F., Muntean, M., Pouliot, G., Keating, T., Zhang, Q., Kurokawa, J., Wankmüller, R., Denier van der Gon, H., Kuenen, J. J. P., Klimont, Z., Frost, G., Darras, S., Koffi, B., and Li, M.: HTAP_v2.2: a mosaic of regional and global emission grid maps for 2008 and 2010 to study hemispheric transport of air pollution, Atmos. Chem. Phys., 15, 11411-11432, doi:10.5194/acp15-11411-2015, 2015.

Jiang, Z., Worden, J. R., Payne, V. H., Zhu, L., Fischer, E., Walker, T., and Jones, D. B. A.: Ozone export from East Asia: The role of PAN, J. Geophys. Res.-Atmos., 121, 6555-6563, doi:10.1002/2016JD024952, 2016.

Kalthoff, N., Bischoff-Gauß, I., Fiebig-Wittmaack, M., Fiedler, F., Thürauf, J., Novoa, E., Pizarro, C., Castillo, R., Gallardo, L., Rondanelli, R., and Kohler, M.: Mesoscale Wind Regimes in Chile at $30^{\circ} \mathrm{S}$, J. Appl. Meteorol., 41, 953970, doi:10.1175/1520-0450(2002)041<0953:mwrica>2.0.co;2, 2002.

Kendall, M. and Stuart, A.: The Advanced Theory of Statistics, Griffin, High Wycombe, UK, 1983.

Kottek, M., Grieser, J., Beck, C., Rudolf, B., and Rubel, F.: World map of the Köppen-Geiger climate classification updated, Meteorol. Z., 15, 259-263, doi:10.1127/0941-2948/2006/0130, 2006.

Lefohn, A. S. and Cooper, O. R.: Introduction to the special issue on observations and source attribution of ozone in rural regions of the western United States, Atmos. Environ., 109, 279-281, doi:10.1016/j.atmosenv.2015.03.030, 2015.

Lin, M., Horowitz, L. W., Oltmans, S. J., Fiore, A. M., and Fan, S.: Tropospheric ozone trends at Mauna Loa Observatory tied to decadal climate variability, Nat. Geosci., 7, 136-143, doi:10.1038/ngeo2066, 2014.

Lin, M., Fiore, A. M., Horowitz, L. W., Langford, A. O., Oltmans, S. J., Tarasick, D., and Rieder, H. E.: Climate variability modulates western US ozone air quality in spring via deep stratospheric intrusions, Nature Communications, 6, 7105, doi:10.1038/ncomms8105, 2015.

Monks, P.: A review of the observations and origins of the spring ozone maximum, Atmos. Environ., 34, 3545-3561, doi:10.1016/S1352-2310(00)00129-1, 2000.

Muñoz, R. C. and Garreaud, R. D.: Dynamics of the Low-Level Jet off the West Coast of Subtropical South America, Mon. Weather Rev., 133, 3661-3677, doi:10.1175/mwr3074.1, 2005.

Myhre, G., Shindell, D., Bréon, F.-M., Collins, W., Fuglestvedt, J., Huang, J., Koch, D., Lamarque, J.-F., Lee, D., Mendoza, B., Nakajima, T., Robock, A., Stephens, G., Takemura, T., and Zhan, H.: Anthropogenic and Natural Radiative Forcing, Chapter 8, in: Climate Change 2013: The Physical Science Basis. Contribution of Working Group I to the Fifth Assessment Report of the Intergovernmental Panel on Climate Change, edited by: Stocker, T. F., Qin, D., Plattner, G.-K., Tignor, M. M. B., Allen, S. K., Boschung, J., Nauels, A., Xia, Y., Bex, V., and Midgley, P. M., Cambridge University Press, Cam- 
bridge, United Kingdom and New York, NY, USA, 659-740, doi:10.1017/CBO9781107415324.018, 2013.

Neu, J. L., Flury, T., Manney, G. L., Santee, M. L., Livesey, N. J., and Worden, J.: Tropospheric ozone variations governed by changes in stratospheric circulation, Nat. Geosci., 7, 340-344, doi:10.1038/ngeo2138, 2014

Nguyen, H., Evans, A., Lucas, C., Smith, I., and Timbal, B.: The Hadley Circulation in Reanalyses: Climatology, Variability, and Change, J. Climate, 26, 3357-3376, doi:10.1175/jcli-d-1200224.1, 2013.

Nzotungicimpaye, C.-M., Abiodun, B. J., and Steyn, D. G.: Tropospheric ozone and its regional transport over Cape Town, Atmos. Environ., 87, 228-238, doi:10.1016/j.atmosenv.2014.01.063, 2014.

Oltmans, S. J., Lefohn, A. S., Shadwick, D., Harris, J. M., Scheel, H. E., Galbally, I., Tarasick, D. W., Johnson, B. J., Brunke, E. G., Claude, H., Zeng, G., Nichol, S., Schmidlin, F., Davies, J., Cuevas, E., Redondas, A., Naoe, H., Nakano, T., and Kawasato, T.: Recent tropospheric ozone changes - A pattern dominated by slow or no growth, Atmos. Environ., 67, 331-351, doi:10.1016/j.atmosenv.2012.10.057, 2013.

Pante, E. and Simon-Bouhet, B.: marmap: A Package for Importing, Plotting and Analyzing Bathymetric and Topographic Data in R, PLoS ONE, 8, 6-9, doi:10.1371/journal.pone.0073051, 2013.

Parrish, D. D., Law, K. S., Staehelin, J., Derwent, R., Cooper, O. 'R., Tanimoto, H., Volz-Thomas, A., Gilge, S., Scheel, H.-E., Steinbacher, M., and Chan, E.: Long-term changes in lower tropospheric baseline ozone concentrations at northern mid-latitudes, Atmos. Chem. Phys., 12, 11485-11504, doi:10.5194/acp-1211485-2012, 2012.

Parrish, D. D., Law, K. S., Staehelin, J., Derwent, R., Cooper, O. R., Tanimoto, H., Volz-Thomas, A., Gilge, S., Scheel, H. E., Steinbacher, M., and Chan, E.: Lower tropospheric ozone at northern midlatitudes: Changing seasonal cycle, Geophys. Res. Lett., 40, 1631-1636, doi:10.1002/grl.50303, 2013.

Rahn, D. A. and Garreaud, R. D.: A synoptic climatology of the near-surface wind along the west coast of South America, Int. J. Climatol., 34, 780-792, doi:10.1002/joc.3724, 2014.

Reich, P. B. and Amundson, R. G.: Ambient levels of ozone reduce net photosynthesis in tree and crop species, Science, 230, 566570, doi:10.1126/science.230.4725.566, 1985.

Rondanelli, R., Gallardo, L., and Garreaud, R. D.: Rapid changes in ozone mixing ratios at Cerro Tololo $\left(30^{\circ} 10^{\prime} \mathrm{S}, 70^{\circ} 48^{\prime} \mathrm{W}, 2200 \mathrm{~m}\right)$ in connection with cutoff lows and deep troughs, J. Geophys. Res., 107, 4677, doi:10.1029/2001JD001334, 2002.

Rutllant, J. A., Muõz, R. C., and Garreaud, R. D.: Meteorological observations on the northern Chilean coast during VOCALSREx, Atmos. Chem. Phys., 13, 3409-3422, doi:10.5194/acp-133409-2013, 2013.

Schnell, J. L., Prather, M. J., Josse, B., Naik, V., Horowitz, L. W., Zeng, G., Shindell, D. T., and Faluvegi, G.: Effect of climate change on surface ozone over North America, Europe, and East Asia, Geophys. Res. Lett., 43, 3509-3518, doi:10.1002/2016GL068060, 2016.

Sekiya, T. and Sudo, K.: Role of meteorological variability in global tropospheric ozone during 1970-2008, J. Geophys. Res., 117, D18303, doi:10.1029/2012JD018054, 2012.
Shi, Y. and Yamaguchi, Y.: A high-resolution and multiyear emissions inventory for biomass burning in Southeast Asia during 2001-2010, Atmos. Environ., 98, 8-16, doi:10.1016/j.atmosenv.2014.08.050, 2014.

Sillman, S. and He, D.: Some theoretical results concerning $\mathrm{O}_{3}$ $\mathrm{NO}_{x}$-VOC chemistry and NOx-VOC indicators, J. Geophys. Res., 107, 4659, doi:10.1029/2001JD001123, 2002.

Simmons, A., Uppala, S., Dee, D., and Kobayashi, S.: ERA-Interim: New ECMWF reanalysis products from 1989 onwards, ECMWF Newsletter, 110, 25-35, 2007.

Škerlak, B.: Climatology and process studies of tropopause folds, cross-tropopause exchange, and transport into the boundary layer, Dissertation, ETH-Zurich, Zürich, Nr. 22036, doi:10.3929/ethz-a-010256937, 2014.

Škerlak, B., Sprenger, M., and Wernli, H.: A global climatology of stratosphere-troposphere exchange using the ERA-Interim data set from 1979 to 2011, Atmos. Chem. Phys., 14, 913-937, doi:10.5194/acp-14-913-2014, 2014.

Sofen, E. D., Bowdalo, D., and Evans, M. J.: How to most effectively expand the global surface ozone observing network, Atmos. Chem. Phys., 16, 1445-1457, doi:10.5194/acp-16-14452016, 2016a.

Sofen, E. D., Bowdalo, D., Evans, M. J., Apadula, F., Bonasoni, P., Cupeiro, M., Ellul, R., Galbally, I. E., Girgzdiene, R., Luppo, S., Mimouni, M., Nahas, A. C., Saliba, M., and Tørseth, K.: Gridded global surface ozone metrics for atmospheric chemistry model evaluation, Earth Syst. Sci. Data, 8, 41-59, doi:10.5194/essd-841-2016, 2016b.

Sprenger, M. and Wernli, H.: The LAGRANTO Lagrangian analysis tool - version 2.0, Geosci. Model Dev., 8, 2569-2586, doi:10.5194/gmd-8-2569-2015, 2015.

Staehelin, J., Harris, N. R. P., Appenzeller, C., and Eberhard, J.: Ozone trends: A review, Rev. Geophys., 39, 231-290, 2001.

Stevenson, D. S., Dentener, F. J., Schultz, M. G., Ellingsen, K., van Noije, T. P. C., Wild, O., Zeng, G., Amann, M., Atherton, C. S., Bell, N., Bergmann, D. J., Bey, I., Butler, T., Cofala, J., Collins, W. J., Derwent, R. G., Doherty, R. M., Drevet, J., Eskes, H. J., Fiore, A. M., Gauss, M., Hauglustaine, D. A., Horowitz, L. W., Isaksen, I. S. A., Krol, M. C., Lamarque, J. F., Lawrence, M. G., Montanaro, V., Müller, J. F., Pitari, G., Prather, M. J., Pyle, J. A., Rast, S., Rodriquez, J. M., Sanderson, M. G., Savage, N. H., Shindell, D. T., Strahan, S. E., Sudo, K., and Szopa, S.: Multimodel ensemble simulations of present-day and near-future tropospheric ozone, J. Geophys. Res., 111, D08301, doi:10.1029/2005JD006338, 2006.

Stohl, A., Wotawa, G., Seibert, P., and Kromp-Kolb, H.: Interpolation Errors in Wind Fields as a Function of Spatial and Temporal Resolution and Their Impact on Different Types of Kinematic Trajectories, J. Appl. Meteorol., 34, 2149-2165, doi:10.1175/1520-0450(1995)034<2149:IEIWFA>2.0.CO;2, 1995.

Streets, D. G., Yarber, K. F., Woo, J.'H., and Carmichael, G. R.: Biomass burning in Asia: Annual and seasonal estimates and atmospheric emissions, Global Biogeochem. Cy., 17, 1099, doi:10.1029/2003GB002040, 2003.

Sudo, K. and Akimoto, H.: Global source attribution of tropospheric ozone: Long-range transport from various source regions, J. Geophys. Res., 112, D12302, doi:10.1029/2006JD007992, 2007. 
Thompson, A. M.: Southern Hemisphere Additional Ozonesondes (SHADOZ) 1998-2000 tropical ozone climatology 2. Tropospheric variability and the zonal wave-one, J. Geophys. Res., 108, 8241, doi:10.1029/2002JD002241, 2003.

Thompson, A. M., Witte, J. C., Smit, H. G. J., Oltmans, S. J., Johnson, B. J., Kirchhoff, V. W. J. H., and Schmidlin, F. J.: Southern Hemisphere Additional Ozonesondes (SHADOZ) 1998-2004 tropical ozone climatology: 3. Instrumentation, station-to-station variability, and evaluation with simulated flight profiles, J. Geophys. Res., 112, D03304, doi:10.1029/2005JD007042, 2007.

Thompson, A. M., Balashov, N. V., Witte, J. C., Coetzee, J. G. R., Thouret, V., and Posny, F.: Tropospheric ozone increases over the southern Africa region: bellwether for rapid growth in Southern Hemisphere pollution?, Atmos. Chem. Phys., 14, 9855-9869, doi:10.5194/acp-14-9855-2014, 2014.

Thoning, K. W., Tans, P. P., and Komhyr, W. D.: Atmospheric carbon dioxide at Mauna Loa Observatory: 2. Analysis of the NOAA GMCC data, 1974-1985, J. Geophys. Res., 94, 85498549, doi:10.1029/JD094iD06p08549, 1989.

Verma, S. K., Kawamura, K., Chen, J., Fu, P., and Zhu, C.: Thirteen years of observations on biomass burning organic tracers over Chichijima Island in the western North Pacific: An outflow region of Asian aerosols, J. Geophys. Res.-Atmos., 120, 41554168, doi:10.1002/2014JD022224, 2015.

Volz, A. and Kley, D.: Evaluation of the Montsouris series of ozone measurements made in the nineteenth century, Nature, 332, 240 242, doi:10.1038/332240a0, 1988.
Wang, Y., Jacob, D. J., and Logan, J. A.: Global simulation of tropospheric $\mathrm{O}_{3}-\mathrm{NO}_{x}$-hydrocarbon chemistry: 3. Origin of tropospheric ozone and effects of nonmethane hydrocarbons, J. Geophys. Res., 103, 10757-10767, doi:10.1029/98JD00156, 1998a.

Wang, Y., Logan, J. A., and Jacob, D. J.: Global simulation of tropospheric $\mathrm{O}_{3}-\mathrm{NO}_{x}$-hydrocarbon chemistry: 2. Model evaluation and global ozone budget, J. Geophys. Res., 103, 10727-10755, doi:10.1029/98JD00157, 1998b.

Wespes, C., Hurtmans, D., Emmons, L. K., Safieddine, S., Clerbaux, C., Edwards, D. P., and Coheur, P.-F.: Ozone variability in the troposphere and the stratosphere from the first 6 years of IASI observations (2008-2013), Atmos. Chem. Phys., 16, 5721-5743, doi:10.5194/acp-16-5721-2016, 2016.

Winer, A. M., Arey, J., Atkinson, R., Aschmann, S. M., Long, W. D., Morrison, C. L., and Olszyk, D. M.: Emission rates of organics from vegetation in California's Central Valley, Atmos. Environ. A-Gen., 26, 2647-2659, doi:10.1016/0960-1686(92)901163, 1992.

Wu, Z. and Huang, N. E.: Ensemble Empirical Mode Decomposition: A noise-assisted data analysis method, Advances in Adaptive Data Analysis, 01, 1-41, doi:10.1142/S1793536909000047, 2009.

Ziemke, J. R., Chandra, S., Oman, L. D., and Bhartia, P. K.: A new ENSO index derived from satellite measurements of column ozone, Atmos. Chem. Phys., 10, 3711-3721, doi:10.5194/acp10-3711-2010, 2010. 